\title{
India's First Green Village — 'Khonoma'
}

\author{
Sapna Papu and Nishant Nathani
}

\begin{abstract}
Mahatma Gandhi, the Father of the Nation, said that "India is in its villages". "If villages perish, India perishes". Gandhi $\mathrm{ji}$ had a vision of self-reliant villages; now we call it green villages. Green village is the village which practices sustainable development in terms of pleasant environment, effective and efficient planning, energy conservation, biodiversity, rain water harvesting, water management, animal husbandry, pesticide and fertilizer free cultivation techniques."Khonoma" is one such village of India, which has been declared as India's first green village by Government of Nagaland and Government of India. This has been made possible by the joint efforts of indigenous habitants of Khonoma Government of Nagaland and Govt. of India through launching the 'Green Village project' of INR 30 million in 2005 . The tribes of Nagaland are born warriors, who used to play head hunting as game and it is said that, they may eat anything that can move. But to make the "Khonama" village, a green, self-reliant and sustainable village; the villagers stopped hunting animals and cutting off the trees. They are practicing Jhoom cultivation, terraced farming, forest conservation, bamboo handicrafts and more. They are following and fully utilizing the govt. initiatives and fund allocated for different schemes like 'Swachh Baharat Abhiyan', 'MNGREGA' and others. Along with this, the village is also preserving its inherent culture, heritage and tradition. This paper will discuss about the practices used in Khonoma, which leads it to become the first green village out of approximately 7,00,000 villages in India.
\end{abstract}

Index Terms - Green village, Jhoom cultivation, community forest, banned hunting, green construction technology, Swachha Bharat Abhiyan.

\section{INTRODUCTION}

Mahatma Gandhi's dream comes true through the village "Khonoma"- India's first green village, where villagers never cut trees and preserve the forest. The village got its name from 'Khwuno', a small plant that is found in abundance around the village. Angami tribes are the main inhabitants of the village, they are known for their bravery and martial skills. The village is also known for its master craftsman's in the art of weaving with bamboo and cane.

Though there is no proper definition of green village, though various sources describes the green village as; Green village is a process that can keep a village attaining sustainable development, Its habitat where one can live in pleasant environment. The village should follow Energy conservation, efficient transportation, biodiversity, waste management, watershed management, rain water harvesting structure, on conventional resources [1].

A green village is a human settlement that enables its residents to live a good quality of life while using maximum

Manuscript received July 12, 2019; revised November 12, 2019.

The authors are with, BMS School of Architecture, Yelahanka, Bengaluru, India (e-mail: sapna_papu@yahoo.co.in,nishantnathani@gmail.com). natural resources. It has successfully solved environmental problems including poverty, poor environmental management and wasteful production and consumption methods [1]. The green villages adopt a holistic approach to sustainability which would result in multi fold benefits, both tangible and intangible. The most tangible benefits are the reduction in water \& energy demand and better handling of solid waste in the village. The intangible benefits of green villages include access to safe drinking water \& sanitation and the basic facilities like healthcare, schools, transport and recreation [2]. "Enebavi, Warangal" is considered as Green Chemical Free Village as they practice chemical free farming, water conservation, farmers are debt-free and overcome from the shortage of seeds and are self sufficient [3]. From the above studies it is understood that the villages who are self sustainable for their living and lively hood and has good infrastructure facilities like food, health, education, electricity, water management, low energy consumption, organic farming techniques, sustainable and vernacular construction techniques, biodiversity, rain water harvesting, water management, animal husbandry and pesticide and fertilizer free cultivation techniques is may be considered as Green Village.

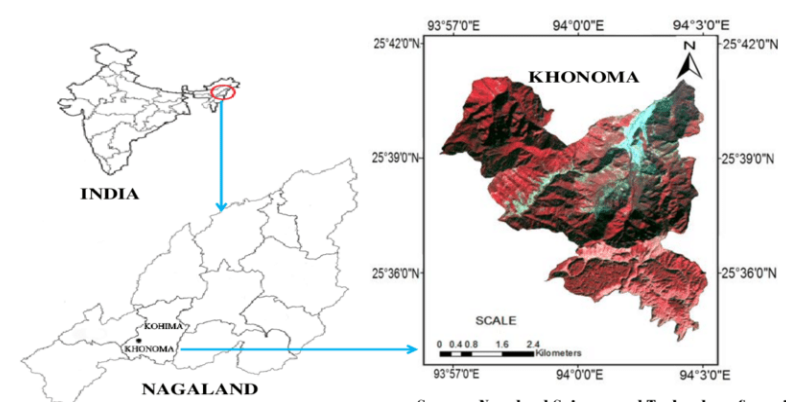

Fig. 1. Location map of Khonoma green village.

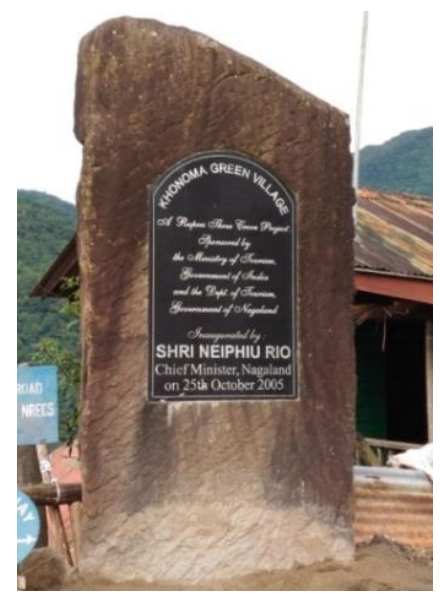

Fig. 2. Green-village monolith.

To promote the green village concept and increase the eco-tourism, tourism department Govt. of Nagaland and 
Union Ministry of Tourism and Culture has launched the 'Khonama Green Village Project' (KGVP) on 25th October 2005, inaugurated by the Nagaland Chief Minister Neiphiu Rio. 'Khonoma' has been identified for the Green village project, due to its advantages over other villages such as location, flora-fauna, forest conservation, ban on hunting, jhoom cultivation, construction technique, social infrastructure and great history. INR 30 million has been sponsored by government for the green village project, the money was used to provide basic civic amenities, hygiene measures, reinforce community infrastructure, prepare the village to receive and show visitors its past and present, solar lights, and viewpoints [4]. KGVP was the first project of its kind and Khonoma is the first Green Village in the country. The aim of the project was to make "Khonoma" a model for all villages in Nagaland and other states for eco-tourism. The project has gained widespread attention in India. Though the government has come forward to help and funded the project, but it was initiated by the local peoples [5].

\section{LOCATION AND APPROACH}

'Khonoma' is located in Dzukou Valley approx $20 \mathrm{~km}$ from Capital of Nagaland, Kohima district and Sechu-Zubza sub district as Fig. 1 [6]. Khonoma is a hilly area at an altitude of 5,320 feet above MSL and spread over the area of $123 \mathrm{sq} . \mathrm{km}$. Village is situated in the beautiful mountains in mysterious way so that one cannot see the village until they cross the ceremonial giant gateway, which welcomes the visitors. The village is almost at the base of mountains and shielded by mountains on all sides, also known as 'hidden village'. A big monolithic stone, engraved with the details of Green Village has been installed at the entry way to village, Fig. 2, photograph taken by author.

\section{DEMOGRAPHY}

Khonoma has population of 1943 with total 424 families residing; as per the census 2011. Among them 919 (47\%) are male and $1024(53 \%)$ are female. As of 2011 census there are 1114 females per 1000 male in the village. $2 \%$ of the whole population is from general caste and $98 \%$ are schedule tribes. Child (aged under 6 years) population of Khonoma village is $10 \%$, among them $48 \%$ are boys and $52 \%$ are girls [7].

TABLE I: CASTE WISE POPULATION 2011 - KHONOMA

\begin{tabular}{|l|l|l|l|l|}
\hline & Total & General & $\begin{array}{l}\text { Schedule } \\
\text { Tribe }\end{array}$ & Child \\
\hline Total & 1,943 & 38 & 1,905 & 189 \\
\hline Male & 919 & 20 & 899 & 91 \\
\hline Female & 1,024 & 18 & 1,006 & 98 \\
\hline
\end{tabular}

Population of the village has decreased by $-33.4 \%$ according to the census of 2001 and 2011 as shown in Table I [7].

\section{HISTORY OF KHONOMA}

After Khonoma green village is considered to be 700 years old settlement, known for its past heritage of fighting and warfare. Naga's has grown up hunting and spending half their life in the woods, head hunting was their one of the favorite game. Khonoma village had etched its name into the history of Indian resistance to the colonial invasion. The village carries the monolith stones engraved by the names of warrior heroes who sacrificed their lives to resist the colonial invasion. Christianity was introduced in the village in 1890 , now most of the villagers are of this faith [8].

\section{SOCIAL STRUCTURE}

Each person of Khonoma, let it be either boy or girl, young or old are the member of one or other bodies of Khonoma such as; village council, Village Development Board, student union, Khonoma Women's Organisation etc. In addition, all villagers are part of an 'age group', such groups are formed by boys and girls in the age group 12-15 (born within specified dates), who carry out social activities like construction of rest-houses, village paths, and the formation of singing and dancing groups. Each age group is assigned a guardian, who is considered a spiritual parent. The 'Morung', popularly known as centre of learning and also the house of decision making, as an important centre of the village [9]. A typical morung is shown in Fig. 3 [10]. Khonoma has high literacy rate of approx $70 \%$, There is good educational infrastructure consisting of six schools in the village [11]. Khonomaians celebrates 1st September is as the village's 'birthday', to celebrate, they come from far and wide.

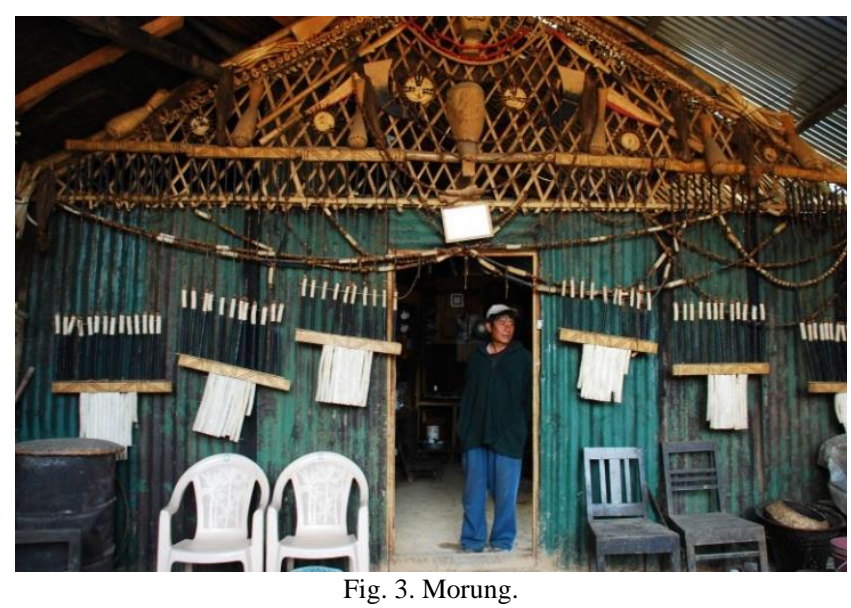

\section{GREEN CONCEPTS OF THE VILLAGE}

After Following concepts are being practiced by the villager to make their village green:

\section{A. Khonoma Nature Conservation and Tragopan Sanctuary (KNCTS)}

The Naga tribes are hunter by born, hunting is the game as well means of livelihood for them. In 1993, they realized that trapogan birds are endangered species, 300 of them were killed in few times for their meat in the village. From then some of the ecologically sensitive villagers launched a crusade against hunting. Twenty five ago, residents of Khonoma, Nagaland, did something that no one else in the country had ever done before. They declared a chunk of their forest as a conservation reserve - the Khonoma Nature 
Conservation and Tragopan Sanctuary. Until then, only the government had identified forests worthy of protection.

KNCTS is a unique example of the community initiative for wildlife and environment conservation in India. The village is preserving about $70 \mathrm{sq} \mathrm{Km}$ of its community forests. The sanctuary is one of the few community conserved areas in India.

The KNCTS is not a legal government body. However, the Village Council Act of Nagaland gives the Village Council authority to devise mechanism for management of forest resources. Therefore, the Village Council and the entire community under the prevalent customary law recognize KNCTS as a legal entity. In 2005, the state forest department initiated a proposal for this area to be declared a Community Reserve under the Indian Wildlife (Protection) Act as amended in 2001. To protect the sanctuary rules were laid down for the management. In which there was financial fine INR 300-3000/- depending on the seriousness of the violation. But more than monetary punishment, the family's loss of face was a more effective deterrent. Youth bodies like, the Khonoma Students Union (KSU) and Khonoma Youth Organization played active role in facilitating this movement they are the one who does monitoring, implementation of rules and levy the fines. Khonoma received the epithet of a 'green village' and accolades in the media. But this success was met with staunch resistance by some fellow villagers.

\section{B. Banned Hunting}

The Naga tribes are known for wildlife hunting for their livelihood. It is said that "they eat everything virtually that moves". But to make the village green the villagers come to the concuss and banned the hunting in entire forest area of the village extending to $125 \mathrm{~km}^{2}$ since 1998 . Within a short span of time after the ban of hunting, sightings of deer, wild boar and porcupine, has been started. Many farmers also reported the damage of their food crops by wild animals. In order to deal with this problem, hunting of animals sighted in the fields is allowed but the meat is not allowed to be sold. The village council also gave permits to hunt wild dogs attacking the mithuns. The KNCTS also gave sanction to penalize individuals if they hunted any other animal than those declared as vermin/pests.

\section{Agriculture: Renewable Jhoom/Shifting Cultivation}

Khonoma is also well-known in agricultural circles for its sophisticated cultivation techniques. Farmers use a form of shifting (jhum) cultivation, in which they change the land for farming for two years and use Nepal alder (Alnusnepalensis) trees interspersed with the crops and cut their branches occasionally. By cutting smaller branches and leaving only the bigger branches they've succeeded in farming without cutting trees. These trees return nitrogen to the soil, thereby helping the land to rapidly regain fertility when farmers abandon it to move on to the next plot. Cairns and Brookfeld (2011) report that a fallow period under managed alder of only two years' duration is sufficient to restore soil fertility for a further two years of cropping. This method solves the problem of soil erosion and enrich the environment with nitrogen this method resist fire and can grow back from nothing.

\section{Terraced Cultivation}

The village has developed the terraced fields for cultivation since ages, primarily used for rice cultivation. For farming they don't use any chemical pesticides or fertilizers instead the villagers use sewage and tree as organic manure. Khonoma is home to over sixty varieties of rice, and a diversity of millets, maize, Job's tears (a tall grain-bearing tropical plant), citrus fruits and other crops.

\section{E. Banning of Logging}

In the early 90's some local youth were involved in extensive logging around the community owned forest. This scale logging operation was endangering the loss of all valuable resources from their forest. The rich timber resources and rich biodiversity under were threat. By 1994 a vast area of forest was cleared by these illegal loggers. Then community meetings called to address illegal logging. These incidences further threatened the community spirit of the villagers who were already divided on grounds of social conflicts. The resistance from the loggers only strengthened the resolve of the community leaders to put an end to these problems.

\section{F. Biodiversity}

Khonoma has majestic mountains, beautiful waterfalls and dense forests. The village is rich in biodiversity a large number of -birds, primates, reptiles, amphibians, orchids, and medicinal plants and many rare flora and fauna have been inventoried as part of the Green Village initiative. The state bird, Blyth's Tragopan, a pheasant now nationally endangered, is reportedly found here. Villagers have taken resolution to conserve the biodiversity and wildlife in the village. Biodiversity of Khonoma village according to their uses has been tabulated in Table II [12]

TABLE II: BIODIVERSITY OF KHONOMA VILLAGE ACCORDING TO THEIR

\begin{tabular}{|l|l|l|l|}
\hline Flora & $\begin{array}{l}\text { No. of } \\
\text { species }\end{array}$ & Flora & $\begin{array}{l}\text { No. of } \\
\text { species }\end{array}$ \\
\hline Timber & 68 & Canes & 16 \\
\hline Fuel wood & 72 & Bamboos & 23 \\
\hline $\begin{array}{l}\text { Edible plant products (wild } \\
\text { fruits and vegetables) }\end{array}$ & 118 & $\begin{array}{l}\text { Dye and colour } \\
\text { yielding plants }\end{array}$ & 04 \\
\hline Mushrooms & 09 & Orchids forest & 06 \\
\hline Medicinal plants & 64 & $\begin{array}{l}\text { Other } \\
\text { products }\end{array}$ & \\
\hline Natural gum extracts & 07 & & \\
\hline
\end{tabular}

\section{G. Solid Waste Management}

Students union of Khonoma takes care of the cleanliness and solid waste management. At every junction of the village garbage bin has been placed and maintained by the student union. The Village Council has made it mandatory for every household to have dustbins. Once in a month, sanitation drive is carried out. Open Defecation has been stopped, Under 'Swachh Bharat' Scheme toilets has been constructed and school children are trained to keep their village and houses clean. The Indian Army has helped construct community assets from public toilets to irrigation facilities. Now, waste generated in the village is being segregated and disposed by incineration [13]. 


\section{H. Water Management}

Each house is connected with a fresh potable water pipe line through government schemes like MGNREGA. Community water tank has been constructed at different location for the proper supply of water to houses. Community also practices the Rain water harvesting system, re-use of water and underground water recharge through pond and well.

\section{Village Power Consumption}

Whole village is properly connected with the electric power supply. CFL or LED bulbs have been used to save power. Air conditioned is not being used by any of the residents. Street light is powered by solar clean technology.

\section{J. Animals Restricted Area}

The animals are not allowed to roam around the habitable space within the village boundary. They are allowed to graze only outside the village boundary to make the village clean from animal defecation and safe from the animals.

\section{K. House Gardening}

The As a part of tradition each house develops a small garden in front of their house. In which they plans the beautiful and vivid colour flower plants, daily use vegetables and medicinal plants, which make the households self sufficient.

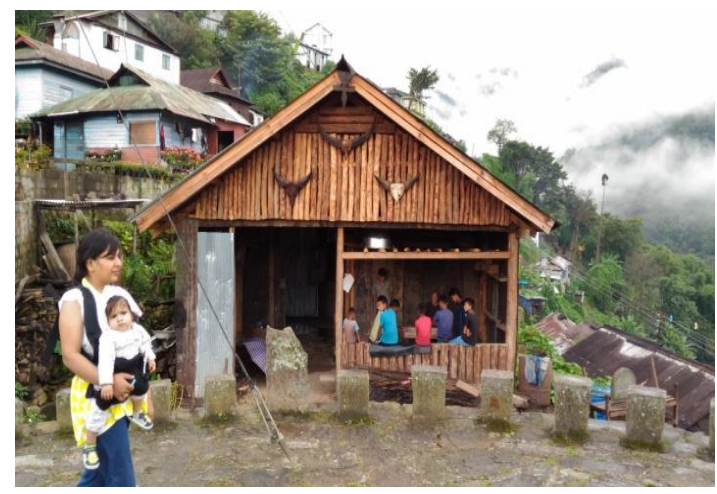

Fig. 4. Wooden house.

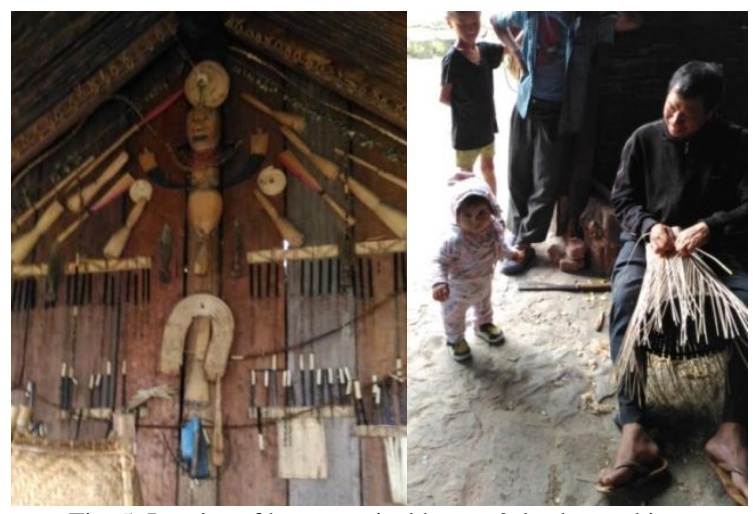

Fig. 5. Interior of house typical house \& basket making.

\section{Cooking in the Centre of House}

The Naga families practice to cook food in the centre of house so that the fumes and smokes kill the insects and the wooden structure could remain intact for years. This practice also helps to keep inside warmer. India had a very rich tradition of understanding of climate responsive and responsible buildings towards nature [14]. Khonoma is one of such villages; where locally available stone, wood and bamboo are the basic construction materials, which have been used for building and other infrastructure developments like steps and staircases, water tanks, community hall etc. Construction activity is also done by local people on self help basis. A typical wooden house has been photographed by author as shown in Fig. 4.

\section{Transport Management}

Although the village is very small but the proper signage's has been used for one way traffic, bus stands etc.

\section{N. Economic Activity}

Agriculture, making baskets and artifacts out of Bamboo, fishing, tourism and guest houses is the main economic activity of the village. An artificial fish pond has been constructed outside the village boundary. A typical house having basket weaving space has been shown in Fig. 5, photograph taken by author.

\section{O. Health Facility}

Fresh air, good food, simple life style and sports are the key, which makes the Khonoma people healthy. Primary health care centre facility is available in the village. Sports and cultural activity spaces has been built at many places with in the village as shown in figure.

\section{ENVIRONMENTAL IMPACT ASSESSMENT (EIA)}

The Since 1994, Centre for Environment Education CEE has played an important role to make the Khonoma a First Green Village of India. EIA has been conducted by CEE, guidelines, codes of conduct and environmental indicators are being worked to avoid any environmental damage that may happen because of tourism [15].

\section{CONCLUSION}

The India is taking a lead role to develop its villages in sustainable model. 'Khonoma' is the successful example of such initiative and became the first green village of India. The village has been placed on the tourism map of the country and has attracted many wildlife enthusiast, birders, conservationists, researchers and tourists. The green village initiative has firstly taken by the indigenous inhabitant of Khonoma and further supported by the government. There is some setback also which Khonama is facing like reduction in population during last decade, since the people are migrating from village to town in search of job, as the village economy is concentrated to group of people who are engaged as tourist guides, home stay owners and performers of cultural songs and dances, agriculture and not to the village as a whole, who are dependent on hunting, though they are confined to a small number of the people. Thus, there is a need to distribute the benefits among all the stakeholders so that the conservation activities can be promoted by everyone.

The soul of India lies in its villages. If the villages are green and villagers are happy, then the smell of pesticides in the food could be avoided and environment could be healthy. 
India is full of variety, vividness and has indigenous way of doing cultivation and use the local ways of doing things which could be amalgamated to new technologies for making them self sustained. Govt. has taken initiative such as 'The National Mission for a Green India' to make villages green. "Enebavi" of Warangal district, Andhra Pradesh is another example of developing as an organic village. Thuruthikkara became Kerala's First Green Village by Focusing on primary sectors like waste management, energy efficiency and environmental conservation. Hatnur, located in the Sangli district of Maharashtra is another village in this row. It is high time to research on our traditional technologies and improves them to meet with the present requirement instead of copying from west [16].

\section{CONFLICT OF INTEREST}

The research conducted is with the mutual understanding and coordination."The authors declare no conflict of interest".

\section{AUTHOR CONTRIBUTIONS}

Prof. (Dr) Sapna Papu, is working on green building and village, she did the literature study on the, first green village of India i.e. Khonoma. She studied and collected all the information through literature and case study. She worked on compilation of data and edited the research paper.

Dr. (Ar) Nishant Nathani visited the site, collected the information on site, conducted the primary survey, compiled the data and written the paper.

All authors had approved the final version.

\section{REFERENCES}

[1] P. P. P. Kadave, "Planning and design of green village," Special Issue of International Journal of electronics, Communication \& Soft Computing Science \& Engineering, pp. 10-14, 2012.

[2] IGBC. (2015). igbc.in. [Online]. Available: https://igbc.in/igbc/redirectHtml.htm?redVal=showgreenvillagenosign

[3] S. A. Sribashyam. (2011). Eenadu Sunday Special. [Online]. Available: http://csa-india.org/wp-content/uploads/2014/11/GREEN-Village-ena bavi.pdf

[4] N. Pathak, "Khonoma village, Kohima," Community Conserved Areas in India - A Directory, pp. 451-454, 2004.

[5] Nagaland. (2014). [Online]. Available: https://www.mapsofindia.com/

[6] O. P. P. Chase, "Soil nutrients and fertility in three traditional land use systems of Khonoma, Nagaland, India," Resources and Environment 2014, pp. 181-189, 2014

[7] Indikosh. (2018). Indikosh. [Online]. Available: https://indikosh.com/vill/282494/khonoma

[8] N. P. Hazarika, (2014). [Online]. Available: http://www.vikalpsangam.org

[9] Morungexpress. [Online]. Available: https://morungexpress.com/morung-still-an-important-aspect-of-learni $\mathrm{ng} /$
[10] Mapsofindia.

(2014). https://www.mapsofindia.com/

[Online].

Available:

[11] B. Patel, "Education for sustainable development: A case study of the community lead conservation and, ecotourism initiatives in Khonoma, in Nagaland state, India," Ahmedabad: Centre for Environment Education Thaltej Tekra, 2008.

[12] P. C. Singh, "People's initiative for conservation of forests and natural resources: A success story Khonoma village forest, Nagaland," $\mathrm{NeBIO}$, pp. 61-67, 2012.

[13] A. Chanda. (2016). Rebel cradle becomes Asia's first green village. [Online].

Available: http://www.newindianexpress.com/thesundaystandard/2016/dec/10/re bel-cradle-becomes-asias-first-green-village-1547794.html

[14] M. R. P. Prakash, "Green building — Traditional approach for future," International Journal of Applied Engineering Research, pp. 185-191, 2014.

[15] CEE. (2014). CEE's intervention to make 'Khonoma' - a 'Green Village' in Nagaland. [Online]. Available: http://www.ceeindia.org:http://www.ceeindia.org/khonoma.html

[16] S. K. Gupta, "Pedagogy for green building: India," International Journal of Environmental Research and Development, pp. 27-32, 2014.

Copyright $\odot 2020$ by the authors. This is an open access article distributed under the Creative Commons Attribution License which permits unrestricted use, distribution, and reproduction in any medium, provided the original work is properly cited ( $\underline{\text { C BY } 4.0})$.

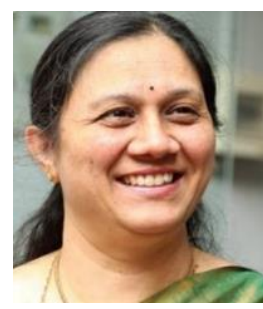

Sapna Papu was born in India on $14^{\text {th }}$ October 1967. She earned her Ph.D. in architecture from JNA \& FA University Hyderabad, India in 2013; post graduate diploma in urban design (M.Arch) CEPT, Ahmedabad, India in 1993 and B.Arch from Mysore University India in 1990. Her focused research area is sustainable and green Architecture. She started her career as practicing architect and worked on more than 100 projects. Subsequently, she joined academics to fulfill her passion towards the research. She is a dynamic and challenging administrator. At present she is the director \& Member Secretary (BoG), BMS School of Architecture Yelahanka, Bangalore - 560064. Her research paper has been published in national and international journals, with a good number of citations.

Professor Papu is the active member of Council of Architecture, India, Indian Institute if Architects, INTACH and other professional bodies.

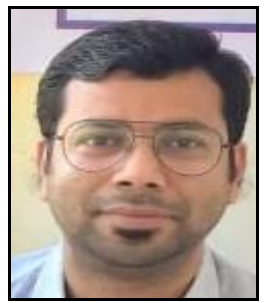

Nishant Nathani was born in India on 9th August 1983. He earned his Ph.D. in transport planning form Amity University, India in 2018; M.Arch from IIT Roorkee, India in 2009. His appetite of learning leads him to pursue the M.Plan. from Institute of town planners India and 3rd masters degree in construction management, NICMAR, India, and B.Arch. from VTU, India. His focused research area is Sustainable and green Architecture.

He started his career as an architect and worked under Architect Hafeez Contractor. Later he joined the academics to fulfill her passion towards the research. At present he is working as associate professor in BMS School of Architecture Yelahanka, Bangalore - 560064. He has published more than 15 research papers in national and international journals, with a good number of citations.

Dr. Nathani is the active member of Council of Architecture, India, Indian Institute if Architects, other professional bodies. 